\title{
Het ACW, de katholieke partij en de taalwetgeving, 1929-1932
}

(Tweede deel) $\left(^{\circ}\right)$

\section{LODE WILS en EMMANUEL GERARD}

In het eerste deel van dit artikel hebben we aangetoond hoe in het begin van 1929 de leiding van het Algemeen Christelijk Werkersverbond / Ligue Nationale des Travailleurs Chrétiens (ACW-LNTC) besloot om de uitwerking van een eigen almomvattend taalstatuut voor het land tot een belangrijk punt te maken van zijn programma voor de parlementsverkiezingen van mei 1929. Hoofdoorzaak was de stuwing uit de Vlaamse basis, die door de Bormsverkiezing in het licht was gesteld en die zich ook in de volgende jaren zou manifesteren, onder meer in sympathie van de christelijke arbeidersmilitanten voor het nationalisme. ${ }^{35}$ Niet de druppel, maar de schep die de emmer deed overlopen, was de noodzaak om de socialistische concurrent vóór te zijn. Wie het archief van het ACW raadpleegt, of de papieren van zijn secretaris P.W. Segers, wordt doorlopend geconfronteerd met de opgave waarvoor de christelijke arbeidersbeweging zich gesteld zag: de gelijke worden van de Belgische Werkliedenpartij. Daarvoor was een zelfstandige partij-opstelling nodig met een eigen programma, ook op Vlaams gebied.

\section{Naar de verkiezingen}

Het ACW-LNTC had aangekondigd dat het zich zou inzetten om zijn radicaal programma van ééntaligheid voor Vlaanderen te verwezenlijken, door propa-

$\left(^{\circ}\right)$ Het eerste deel verscheen in Wetenschappelijke Tijdingen, jg. 55, 1996, nr. 4, pp. 235-255.

35. Enkele voorbeelden: op 12 november 1931 schreef P.W. Segers aan F. Van Cauwelaert "dat wij bijzonder waakzaam zijn voor wat aangaat het nationalistisch gevaar voor onze arbeidersorganisaties [...] Zo zijn er onbetwistbaar in de vakbeweging in Turnhout en ook in Antwerpen syndicale leiders die meer sympathie hebben voor de politiek van de Vlaamse nationalisten dan voor het programma van het $A C W$ of van de katholieke Vlamingen. "In de Middenraad van het ACW werd op 20 maart 1932 een bespreking gehouden over de betrekkingen tussen het ACW en de KAJ, waarbij een aanwezige vroeg: "Hoe moeten wij handelen tegenover Kajottersafdelingen die weigeren betrekkingen te hebben met het $A C W$ omdat zij verklaren Vlaamse nationalisten te zijn?"KADOC, Papieren Segers, nrs. 15.1.10 en 6.2.1. 
ganda en politieke actie. Het Gentse dagblad van de beweging, Het Volk, liet het in elk geval niet bij berichtgeving over de vergadering van de Middenraad van 13 maart 1929 waarop het "taalstatuut" was aanvaard. Het zette op 15 maart de strijd in met een uitvoerig hoofdartikel Oplossing van het Taalvraagstuk in België. "Een historische gebeurtenis: voor de eerste maal is er verstandhouding tussen Walen en Vlamingen om het taalvraagstuk een bepaalde en deugdelijke oplossing te geven. Het zijn de christen-democraten ${ }^{36}$ die voor ons land die hoge daad hebben gesteld ... Het 'ding' dat in Vlaanderen de naam van franskiljonisme gekregen heeft, poogde zich in een allerlaatste loopgracht nog wat staande te houden, door te schreeuwen dat Vlaanderen door de eeuwen heen tweetalig is geweest, het nog is en het blijven moet. De nuchtere en praktische Waalse en Vlaamse democraten hebben echter dat Franse grachtje in Vlaamse grond dicht getrappeld en het terrein bouwvaardig effen gelegd". ${ }^{37}$ Zo gemakkelijk werd dat franskiljons grachtje niet gedempt. Op 16 maart publiceerden Jules Destrée en Camille Huysmans het socialistische Compromis des Belges, dat was ondertekend door vijftien Waalse en twaalf Vlaamse volksvertegenwoordigers, van alle arrondissementen behalve Brussel. Het stuk hield het wallingantisch programma van Destrée in, verdoezeld in gewilde onduidelijkheid: behoud van de eentaligheid voor Wallonië en voor de Franstalige ambtenaren en officieren; behoud of zelfs herstel van de tweetaligheid in Vlaanderen via provinciale of gemeentelijke referendums; erkenning van de rechten van de taalminderheden in Vlaanderen, zelfs daar waar ze niet bij referendum algemene tweetaligheid zouden kunnen afdwingen; vrije verfransing van het Brusselse en de taalgrens. ${ }^{38}$ $\mathrm{Nu}$ de socialistische partij zich opmaakte om bij de aanstaande parlementsverkiezingen een nieuwe doorbraak te verwezenlijken, na die van 1919 en 1925, had zij in haar geheel het wallingantische programma aangenomen dat voor haar Waalse meerderheid zo belangrijk was. Haar Oost- en West-Vlaamse vleugel onder de leiding van Edward Anseele, met het Gentse dagblad Vooruit als tolk, had nooit verzet aangetekend tegen die Waals-socialistische eisen. $\mathrm{Nu}$ had ook de rest van de partij, onder de leiding van het Vlaamsgezinde Antwerpen, zich erbij neergelegd. Huysmans persoonlijk had nooit de eentaligheid van Vlaanderen op zijn programma gehad, en zou die ook later blijven afwijzen als een verkeerde oplossing. ${ }^{39}$

36. "De christen-democraten" betekende destijds: de christelijke arbeidersbeweging, in het bijzonder het ACW en zijn mandatarissen.

37. Geciteerd door Th. LuYKX in: S.H. SCHOLL (ed.), 150 Jaar Katholieke Arbeidersbeweging in België (1789-1939), deel III, Brussel, 1966, p. 153.

38. L. WILS, Bormsverkiezing en Compromis des Belges, in: L. WILS, Vlaanderen, België, GrootNederland, Leuven, 1994, pp. 374-377.

39. L. Wils, Bormsverkiezing [...], pp. 365-374. 
De tegenstelling tussen de twee voorstellen van taalstatuut, het christen-democratische en het socialistische, viel onmiddellijk op. ${ }^{40}$ In de franskiljonse pers werd het eerste fel aangevallen, maar het tweede toegejuicht. Zo in Pour l'Unité, het maandblad van de Ligue nationale pour l'Unité belge zoals de herdoopte Ligue contre la flamandisation de l'Université de Gand nu heette. In het maart-nummer van dit orgaan van Jacques Pirenne werd het ACW-manifest voorgesteld onder de titel Contre la paix linguistique, als "un véritable attentat contre la libertélinguistique des Belges. Que fait-on des minorités françaises? On leur dénie tout droit." En dat terwijl ze wel bescherming vragen voor de Duitse minderheid in Wallonië en voor de Vlaamse in Brussel! - De socialistische tekst werd daarentegen voorgesteld als een oplossing Pour la paix linguistique: "Nous applaudissons des deux mains à ce 'compromis des Belges'”. - Een zelfde beoordeling van beide manifesten in het fel anti-Vlaamsgezinde, toonaangevende liberale maandblad Le Flambeau op 1 april. De liberalen, ook de meeste Vlaamse liberalen, hielden met de wallinganten vast aan de tweetaligheid van Vlaanderen, waarmee nu ook de Vlaamse socialisten hadden ingestemd.

Wel trachtten vele katholieke en socialistische persorganen en politici hun publiek wijs te maken dat "het andere manifest ongeveer overeenkomt met het onze". ${ }^{41}$

De stellingname van het ACW en de Katholieke Unie werd betwist door een aantal katholieke persorganen die, zoals het maandblad La Revue Générale, vasthielden aan de rechten van de Franstaligen in Vlaanderen. Maar, anders dan de liberale en socialistische wallingantische bladen, verkondigden die niet tegelijk de eentaligheid van Wallonië. La Terre Wallonne noemde als tegenstanders van haar eentaligheidseis "les petites gazettes catholiques de Tournay, de Liège et de La Louvière qui approuvent M. Wallez"42. Zij pleitten zoals de priester Norbert Wallez in zijn Brussels dagblad Le XXe Siècle voor tweetaligheid van de ambtenaren, maar dan ook in Wallonië. Wallez vroeg, tegen La Libre Belgique in, sinds jaren met kracht begrip voor de Vlaamse eisen.

Maar de voorzitter van het ACW en van de Katholieke Unie, Edmond Rubbens, reageerde dat de oplossing van de tweetaligheid van de ambtenaren misschien ideaal, maar in feite utopisch was: "Les moeurs sont plus importantes que les lois et ne se laissent pas régenter par elles!"’3 De Waalse eis van eentaligheid voor hun

40. Zo in De Standaard van 17 maart, door P.V.M.: de socialisten hebben "de deur opengelaten voor het behoud van het tweetalig regime... Alleen door het ACW werd klare wijn geschonken”.

41. Zie behalve L. WiLs, Bormsverkiezing [...] ook P. De KeYser en C. Debaive, Rondom het Vergelijk der Belgen, in: Ontwikkeling. Maandschrift uitgegeven onder de bescherming van de BWP, okt.-nov. 1929, pp. 645-687.

42. J. DelaunaY in: La Terre Wallonne, jg. XX, april-sept. 1929, p. 179.

43. Rubbens in: Le XXe Siècle, 2 mei 1929. 
ambtenaren was onoverkomelijk, bijgevolg was gelijkheid slechts mogelijk door eenzelfde eentaligheid in Vlaanderen. Rubbens verdedigde het taalstatuut van het $\mathrm{ACW}$ ook in het toonaangevende weekblad La Revue Catholique des Idées et des Faitsvan priester Van den Hout. ${ }^{44}$ Dat blad versterkte in 1929 zijn campagne voor de erkenning van het Vlaamse karakter van Vlaanderen als de enige oplossing van het communautaire vraagstuk. De heel kleine tweetalige of Franstalige minderheid moest heel goed Nederlands leren, en de regering moest durven regeren zonder zich te laten ophouden door het geschreeuw (van liberale franskiljons), punt! Het was duidelijk dat het ACW er werk van maakte "om langs de weg der eigen organisatie, de openbare mening te bewerken". Het taalstatuut vormde een hoofdbrok in zijn uitgebreid verkiezingsprogramma, dat het als overdruk uit De Gids op Maatschappelijk Gebied verspreidde. Bleef de vraag of het na de verkiezingen "zijn vertegenwoordigers in alle openbare lichamen voor de doorvoering dezer hervorming zou doen ijveren".

Op 26 mei 1929 gaven de parlementsverkiezingen enkele belangrijke verschuivingen te zien, vergeleken met $1925 .{ }^{45}$ De liberalen wonnen $1,91 \%$ van de stemmen bij, de Fronters 2,44\%. De verliezers waren de socialisten met 3,41\% en neutrale snipperlijsten met 1,40\%. Katholieken en communisten behielden ongeveer hun stemmenpercentage, al verloren ze elk één zetel in de Kamer. De uitslagen krijgen maar hun betekenis wanneer ze per landsgedeelte worden ontleed. In Vlaanderen hadden de Fronters een sprong vooruit gemaakt die hen op 9,9\% bracht van het Vlaamse kiezerskorps, dat ten koste van de socialisten en van de katholieken. In Brussel hadden de liberalen een belangrijke overwinning geboekt ten nadele van de socialisten. In Wallonië tenslotte hadden de twee regeringspartijen winst behaald zowel op de Belgische Werkliedenpartij (BWP) als op neutrale lijsten. Deze verkiezingen brachten niet de verhoopte doorbraak van de BWP, eerder een ernstig verlies. Ze betekenden een uiting van flamingantisch ongeduld, en dat voor de eerste keer ook in de socialistische achterban. ${ }^{46}$ In Wallonië en enigszins zelfs in Brussel betekenden ze een goedkeuring van de regeringspolitiek van toegevingen aan de Vlaamsgezinden, die waren gebeurd inzake het leger en de genade voor activisten, tegen fel socialistisch-wallingantisch verzet in. De Waalse

44. Op 5 en 12 april 1929. Over de publicistische bedrijvigheid van Rubbens terzake, zie M. Cordemans, Edmond Rubbens. Een levensverhaalmeteen bloemlezing uit zijn werken, Gent, s.d. (1966), pp. 265-277.

45. We nemen hier de ontleding over van E. De Smet, R. Evalenko en W. Fraeys, Atlas des élections belges 1919-1954, Brussel, 1958.

46. Over de Vlaamsgezindheid bij de socialistische basis in Antwerpen, zie J. Hunin, Links van de Belgische Werkliedenpartij. Communisme in Antwerpen tussen de twee wereldoorlogen, in: Belgisch Tijdschrift voor Nieuwste Geschiedenis, jg. 25, 1994/1995, pp. 569-608. 
christen-democraten waren niet afgestraft voor het communautair programma van het $\mathrm{ACW}$, zoals ze gevreesd hadden. Integendeel hadden ze voor de eerste maal een doorbraak behaald met drie nieuwe volksvertegenwoordigers en twee senatoren. Het kiezerskorps scheen haar afkeuring te hebben uitgesproken voor het wallingantische opbod van de socialisten.

De regering kon niet anders dan uit dat alles besluiten trekken. In de kabinetsraad van 29 mei commentarieerde Eerste minister Jaspar dat ze haar politiek moest voortzetten. De katholieke Minister van Landsverdediging de Broqueville voegde eraan toe dat ze moest "préparer dans le calme la solution de la question flamande". Er was nu geen sprake meer van Waalse onrust die moest worden weggenomen, zoals nog na de Bormsverkiezing. ${ }^{47}$ Nog diezelfde dag zegde Jaspar, in een toespraak in zijn electorale basis Luik: de taalkwestie is een regeringszaak, de regering zal een totale oplossing voorleggen; ik wil het Belgische eeuwfeest van 1930 in vrede vieren. ${ }^{48}$ In de loop van juni legde hij verschillende zulke publieke verklaringen af: "Ik wil de taalkwestie oplossen. I $k$ wil niet aan het bewind blijven, indien $i k$ daarin niet slaag." En zelfs Minister van Buitenlandse Zaken Hymans, de liberale leider in de regering, die zich een taai tegenstander van de Vlaamse eisen getoond had, erkende in het openbaar dat men "de taalkwestie moest aanpakken met een nieuwe geest en met buitengewoon veel goede wil". 49

\section{Een eigen ACW-politiek}

Op 20 juni 1929 vergaderde het Hoofdbestuur van het ACW, met op de agenda: 1) de verkiezingen in verband met onze sociale organisatie; en 2) de verkiezingen en het taalvraagstuk. De notulen vermelden 40 aanwezigen, 3 verontschuldigden en 19 andere afwezigen. ${ }^{50}$

De proost Louis Colens stelde vast dat de beweging groeide, ondanks haar lidmaatschap van de Katholieke Unie. Dat lidmaatschap doet ons afbreuk, maar

47. In zijn verslag van de ministerraad schreef De Standaard: "Al de ministers zijn het eens om te verklaren dat de Vlaamse kwestie binnen de kortst mogelijke tijd moet worden opgelost. En de Vlaamse ministers staan erop dat de oplossing in de zin van de dagorde van de christelijke arbeiders zou getroffen worden." En op dezelfde 30 mei schreef het blad in zijn commentaar op de verkiezingsuitslag, dat de regering moest werk maken van de Vlaamse kwestie: "Het ACW heeft voor een formulering gezorgd, met als basis de eentaligheid van Vlaanderen en Wallonië."

48. K. De CLERCK (ed.), Kroniek van de strijd voor de vernederlandsing van de Gentse Universiteit, Brugge, 1980.

49. L. WiLS, Bormsverkiezing [...], pp. 359-360.

50. KADOC, Papieren Segers, dossier 5.1.4. Behoudens andere verwijzing komen onze gegevens hieruit. 
het versterkt onze invloed binnen de katholieke zuil. "Een merkelijk deel van de jeugd loopt naar het nationalisme over." Dat werd bevestigd door de Kortrijkse parlementsleden Catteeuw en Bossuyt, maar deze laatste zegde dat het "heel wat burgers, vlasbazen en boerenzoons" waren die in hun streek voor de nationalisten gestemd hadden, terwijl de afzonderlijke christelijke arbeiderslijst integendeel 4000 stemmen had bijgewonnen.

Drie Waalse verkozenen benadrukten dat bij hen het verschijnen op een katholieke eenheidslijst catastrofale gevolgen had voor de arbeidersbeweging, omwille van het wantrouwen tegen de katholieken. "Gemeenten die christelijke mutualiteiten hebben met 600 à 800 leden, stemden haast zuiver socialistisch. "We moeten in de Katholieke Unie een statuut hebben, erkend worden door de andere katholieke groeperingen, in het regeringsprogramma en in de samenstelling van de regering. ${ }^{51}$ In het Franstalige landsgedeelte stond de arbeidersbeweging zwak binnen de katholieke zuil. De conservatieven weigerden er haar het monopolie van de sociale actie onder de werklieden toe te kennen, vandaar haar eis van "erkenning door de andere katholieke groeperingen", eis van een monopolie van sociale werking onder de arbeiders, die sinds jaren voor spanningen zorgde en die tot scheuringen zou leiden..$^{52}$ Wat ons hier interesseert is, dat dit vooral Waalse verlangen om zich afzonderlijk als een volwaardige partij te manifesteren binnen de katholieke zuil, ook de wil zou versterken om een eigen flamingantische ACW-taalpolitiek te voeren.

Het was voorzitter Rubbens die het tweede punt op de dagorde aansneed. Hij "drukt erop dat wij inzake het taalvraagstuk onze verantwoordelijkheid moeten nemen. Het taalstatuut van het $A C W$... wij hebben thans tot plicht om deze gedachten uit te werken. Welke tactiek is er nu te volgen? Wij zouden een algemeen wetsvoorstel kunnen uitwerken en het aan de regering voorleggen. Mijns inziens ware het best in onderhandeling te treden met de regering om te vernemen wat haar plannen zijn en om onze opvattingen in herinnering te brengen. Dat is beter dan het publiceren van moties." Dat de regering een commissie zou samenstellen om het vraagstuk te onderzoeken, moest volgens Rubbens vermeden worden, vermits het Vlaamse programma al bekend was. "Wij moeten duidelijk zeggen dat louter wettelijke hervormingen niet volstaan, zelfs wanneer zij volledig worden toegepast. Er moet een andere geest komen in de leidende middens, een vernieuwde mentaliteit die te herkennen is door benoemingen, enz."

51. Aldus Bodart van Charleroi, die werd bijgetreden door Mathieu van Namen en Winandy van Verviers. Tschoffen van Luik stuurde het duidelijkst aan op een minister-portefeuille voor een Waals christen-democraat; het ACW telde nu 21 van de 76 katholieke volksvertegenwoordigers. 52. E. Gerard, De katholieke partij in crisis, Leuven, 1985, pp. 252-267 en 315-318. 
De Mechelse volksvertegenwoordiger Van Isacker stelde voor om de discussie te verdagen ten einde overleg te plegen met de Vlaamse Kamergroep. De Brugse proost Logghe "verzet zich niet tegen een overleg met de Vlaamse Kamergroep, maar wenst dat eerst en vooral het Werkersverbond als zodanig zijn houding bepale." Daarvoor kreeg hij steun van de Luikenaar Tschoffen, en Van Isacker verklaarde zich akkoord. Logghe ging voort: "Wij mogen in geen geval nog een onvoldoende of een gebrekkige oplossing aanvaarden; dit zou voor onze organisaties en voor het land een ramp zijn." Er werd beslist dat een delegatie van tien personaliteiten een onderhoud zou aanvragen bij de Eerste minister.

Op 24 juni werd de delegatie door Jaspar ontvangen, nadat ze zich even tevoren had beraden. ${ }^{53}$ De verslagen van beide samenkomsten zijn in het Frans gesteld, wat ons herinnert aan de klacht van Honoré Maes dat bij beperkte topvergaderingen in Brussel de voertaal het Frans was.

Op het beraad vooraf "zette minister Heyman uiteen welke hervormingen hij zinnens was in te voeren in de sociale wetgeving: inzake verzekeringen, pensioenen, gezinstoelagen, arbeidsongevallen, toezicht op de verzekeringen, vakonderwijs, enz. "Bodart en Tschoffen zegden dat daarover openbare beloften moesten gevraagd worden, en Tschoffen voegde erbij: ook over het taalstatuut. Logghe vroeg radicale en dringende maatregelen op taalgebied, onmiddellijk voor de Gentse universiteit waarover geen commissie meer nodig was, en benoemingen die de gemoederen zouden kalmeren. Cyrille Van Overbergh, de voorzitter van de Democratische groep van de Senaat, ondersteunde die eis. Bodart bracht de vertegenwoordiging in de schoot van de regering te berde, waarop Segers tussenkwam: akkoord, maar niet ten koste van de Vlamingen die al ondervertegenwoordigd zijn; een toegevoegde derde christen-democratische minister moet een Waal zijn.

Aan Jaspar verklaarde Rubbens namens de delegatie dat de christelijke arbeiders de voortzetting wilden van de sociale politiek der regering, en vooral de volledige en snelle oplossing van de taalkwestie in de zin van het taalstatuut van het ACW. Jaspar antwoordde: wend u voor de sociale politek tot minister Heyman, die het vertrouwen van de regering heeft. Hij ging wel in op de taalkwestie en verklaarde op verzoek van het ACW af te zien van een gemengde commissie van parlementsleden en anderen om die kwestie te bestuderen. Hij beriep zich op zijn tussenkomsten voor een striktere toepassing van de taalwetgeving, en op zijn benoeming van een flamingantische gouverneur van Limburg, Hubert Verwilghen, "mais que par contre la presse flamande ne désarme jamais contre lui [...] M. Jaspar assure la délégation des Travailleurs Chrétiens qu'il ne ménagera aucun effort pour réaliser

53. De volksvertegenwoordigers Poullet en Mathieu bleven afwezig; de voorzitter van het ACV, René Debruyne, woonde wel het onderhoud bij, maar niet het beraad vooraf. De adjunct-secretaris Behogne nam in geen van beide het woord. 
cette réforme. Il a d'ailleurs à cet égard déclaré à plusieurs reprises qu'il résoudrait la question linguistique, ou qu'il abandonnerait ses charges actuelles. "Zulke verklaringen waren niet zonder belang, vermits ze door de persmededeling van het ACW in de openbaarheid kwamen.

Bodart vroeg dan, namens de delegatie en ondersteund door Logghe, de opname van een derde, Waalse christen-democraat in de regering. Jaspar beloofde daarvoor, samen met de liberalen, een oplossing te zoeken tegen de heropening van de parlementaire zittijd in november; hij zou eventueel afstand kunnen doen van zijn portefeuille van Koloniën, en alleen premier blijven.

Het ACW had opnieuw de toon gezet op taalgebied. De Katholieke Vlaamse Landsbond, waarvan het bestuur op 23 juni vergaderde met de gewestelijke afgevaardigden en met parlementsleden ${ }^{54}$, en de Kamergroep die pas op 27 juni voor de eerste keer na de verkiezingen bijeenkwam, hadden het nakijken. Van Cauwelaert was daar wat geïrriteerd over. ${ }^{55}$ Maar toch bleef hij degene die langs die twee kanalen de inhoud van de flamingantische eisen bleef bepalen, evenals de tactiek. ${ }^{56} \mathrm{Hij}$ had namens de Kamergroep een onderhoud met Jaspar op 1 juli.

\section{Een slijtageslag}

In de hoop de regeringspartijen en het land mee te krijgen, vermenigvuldigde de Eerste minister zijn verklaringen over de noodzaak om de Vlaamsgezinde opinie te bevredigen. Maar op 3 juli 1929 antwoordde de liberale partijleider Albert Devèze, in Le Soir, op de katholieke Vlaamse eis van het minimumprogramma met de vernederlandsing van de Gentse universiteit voorop: de liberalen willen ook een

54. AMVC, Dossier Frans Van Cauwelaert, C 1954/B, Briefwisseling 19-29 juni 1929; KADOC, Papieren Poullet, nr. 101.

55. Van Cauwelaert zegde in de Kamergroep, blijkens de notulen: "Christelijke arbeiders hebben reeds hun mening uitgedrukt: eerst Gent, dan commissie. Goed standpunt. Beter ware het geen initiatief van de christelijke arbeiders. Best alle Vlamingen samen”; KADOC, Papieren Van Isacker. Op het congres van de Katholieke Vlaamse Landsbond op 3 en 4 augustus zou de secretaris Claes verklaren: "Het ware echter noodlottig indien de Standsorganisaties den Landsbond moesten witschakelen en alleen, elk voor zichzelf, de verwezenlijking der Vlaamse eisen naar eigen zienswijze wilden nastreven." Waarop Rubbens repliceerde "dat men er het ACW geen verwijt kan van maken dat het, na akkoord met Waalse vrienden, een princiepsverklaring omtrent het Vlaamse programma openbaar heeft gemaakt. Spreker gaat verder akkoord om met het bestuur van de Landsbond samen te werken. "Tiende Congres van den Kath. Vlaamschen Landsbond, Dendermonde 3-4 Oogst 1929. Volledig Verslag [...], Brussel, s.d., pp. 15 en 22-23.

56. Dat blijkt o.a. duidelijk uit een verslag door P.J. Broekx aan Poullet, 17 juli 1929, over een beperkte vergadering betreffende de Kamergroep; KADOC, Papieren Poullet, nr. 95. 
globale oplossing, maar die is alleen aanvaardbaar als ze de minderheden eerbiedigt. ${ }^{57}$ Net in die periode bevestigde de Volkenbond het recht van de Duitse en andere minderheden in de staten die na de Wereldoorlog gevormd waren, op een culturele eigenheid zonder assimilatie.

Op het jaarlijkse partijcongres van de socialisten, op 7 en 8 juli, sprak volksvertegenwoordiger Piérard van Bergen voor eentaligheid (in Wallonië) maar voor erkenning van de Franstalige minderheid in Vlaanderen en tegen vernederlandsing van de Gentse universiteit. Hij stuitte op verzet van François Gelders uit Vilvoorde en er werd beslist het talenvraagstuk te behandelen op een buitengewoon congres. Niet alleen de Belgische, maar ook de Vlaamse socialisten toonden openlijk hun verdeeldheid nu de grote strijd over het toekomstig taalstatuut was losgebarsten. Terwijl het Gentse dagblad Vooruit tijdens de volgende dagen stelling nam voor de eentaligheid van Vlaanderen, bevestigde de Antwerpse leider Camille Huysmans, die als de verpersoonlijking van de socialistische Vlaamsgezindheid gold, zijn gehechtheid aan de rechten van de minderheden. Volgens hem hadden in Vlaanderen niet alleen ingeweken Walen, maar ook autochtone Franstaligen die rechten..$^{58}$

Daartegenover zegde Frans Van Cauwelaert op het congres van de Katholieke Vlaamse Landsbond op 4 augustus: "Vlaanderen Vlaams, dit betekent dat niet alleen de individuele Vlaming recht heeft op Vlaams onderwijs, leger, gerecht en bestuur; maar ook dat het Vlaamse volk als geheel het recht heeft op culturele gaafheid. Daarom ontzeggen wij elk bestaansrecht aan taalminderheden in Vlaanderen. Wij willen niet dat zij als eilanden van verfransing de ongezonde verhoudingen in ons land blijven bestendigen. $" 59$

De regeringsleider Jaspar was zeker bereid om de rechten van "de individuele Vlaming"te waarborgen, maar die van "het Vlaamse volk als geheel", die niet werden erkend door de meeste liberalen en socialisten in Vlaanderen zelf, en evenmin door de aartsbisschop van Mechelen? Want kardinaal Van Roey had dezelfde opvatting als Huysmans over het recht van de huisvader in Vlaanderen op een keuze van Franstalig onderwijs voor zijn kinderen. ${ }^{60}$ En koning Albert was een

57. C.H. HöjER, Le régime parlementaire belge de 1918 à 1940, Uppsala-Stockholm, 1946, pp. 187-188.

58. L. WiLS, Bormsverkiezing [...], pp. 377-378. Interview van C. Huysmans in La Nation Belge van 2 augustus, geciteerd in de Revue Générale van 15 augustus, pp. 250-253, met als commentaar van Auguste Mélot: "Il est impossible de formuler une invite plus claire aux libéraux" om een socialistisch-liberale regering te vormen.

59. M. Van Mechelen, Kroniek van Frans Van Cauwelaert 1880-1961, Beveren-Antwerpen, 1980. Tiende Congres [...] Volledig Verslag [...], pp. 104-105.

60. Op 22 november 1929 schreef Van Roey aan de bestuurder van De Standaard om de campagne van de krant tegen denationalisatie door Franstalige scholen in Vlaanderen af te keuren, 
overtuigd verdediger van algemene tweetaligheid in Vlaanderen. ${ }^{61}$ Op 18 juli 1929 schreef ACW-secretaris Paul Willem Segers, mede namens de proost Colens, aan voorzitter Rubbens een lange, dringende oproep: welke invloed oefenen wij uit, nu de regering een oplossing van de taalkwestie voorbereidt? Worden onze leiders nu geraadpleegd? "Wat is er te doen opdat het Werkersverbond niet langer in de hoek worde geschoven? [...] Hoe kunnen wij voor onze mensen verschijnen wanneer de indruk gewekt wordt dat wij, die voor de verkiezing het initiatief schenen te nemen, [...] roerloos zijn gebleven?[...] Is men in de regering wel overtuigd dat wij ons in geen geval mede verantwoordelijk zullen maken voor een 'compromis' met de liberalen dat onvoldoende is?"

De regering was toen vooral begaan met de conferentie van Den Haag over de Duitse herstelbetalingen die voor België heel belangrijk waren. Gevolg was dat ze de Vlaamse kwestie voor zich uitschoof. Wel vergaderden er op 10 juli 23 Waalse en Brusselse katholieke volksvertegenwoordigers om een tegengewicht te vormen tegen de stellingname van de Vlaamse Kamergroep. Daaruit groeide het initiatief tot een gemeenschappelijke commissie met de Kamergroep. Die commissie hield tussen 12 september en 31 oktober zes bijeenkomsten, maar legde geen verklaring af. ${ }^{62}$ Op 17 september stuurde volksvertegenwoordiger Bodart aan Behogne het Cahier des griefs et des revendications de la Wallonie die werd verspreid door de Assemblée Wallonne, met verzoek om een snel en gedetailleerd advies daarover van het bureau van het ACW. Hij werd op zijn wenken bediend, want al op 20 september ging de commentaar naar de zeven leden van de parlementaire Groupe démocratique wallon. Daarbij werd brandhout gemaakt, niet alleen van het Cahier, maar ook van de begeleidende circulaire. De wallingantische overdrijvingen en scheve voorstellingen werden nuchter maar hard aan de kaak gesteld. Het onderscheid dat de Assemblée maakte tussen "autochtone minderheden" in Vlaanderen, die recht zouden hebben op taalbescherming, tegenover de andere in Wallonië, werd omgedraaid: wie van zijn geboorte af in een streek woont, heeft er gemakkelijker

met de dreiging om die afkeuring publiek te maken. Op 2 januari 1930 meldde Bouweraerts aan Van Cauwelaert dat Van Roey aan een delegatie van de Landsbond had gezegd: "De vrijheid van de huisvader' is een christelijk princiep”. AMVC, Dossier Frans Van Cauwelaert, C 1954/B. Zo schreef de aartsbisschop ook aan senator Rutten; L. WiLs, Honderd jaar Vlaamse Beweging, Deel 2: Geschiedenis van het Davidsfonds, 1914-1936, Leuven 1985, p. 162 (118).

61. L. WILS, De taalpolitiek van Koning Albert I, in: Wetenschappelijke Tijdingen, jg. 55, 1996, nr. 3, pp. 197-203.

62. Behalve de initiatiefnemer J. de Geradon namen hieraan deel de Montpellier, Winandy, Sinzot en Carton voor de Franstaligen, met Van Dievoet, Van Isacker, De Schryver, Van Hoeck, Blavier en Rubbens. De K.V. Kamergroep had op 31 juli tot deze onderhandelingen beslist; notulen in KADOC, Papieren Van Isacker. Verder persberichten in De Standaard, en AMVC, Dossier Frans Van Cauwelaert, C 1954/K, 14 en 20 september. 
de taal van geleerd dan een inwijkeling; dus kunnen we niet de eentaligheid van de overheid aanvaarden daar waar talrijke Vlaamse gezinnen wonen. ${ }^{63}$

Omgekeerd: nadat de Assemblée Wallonne, zonder medewerking van de Vlamingen, het regime bepaald heeft dat best past voor Wallonië, hoort het dat ze aan de Vlamingen alléén overlaat hoe het in Vlaanderen moet. Bij de passus over de Universiteit Gent was de commentaar kortaf: "Flamandisation complète et intégrale. "Bij de voorstellen om Wallonië te beschermen tegen de Vlaamse meerderheid door federaliserende hervormingen, werd genoteerd dat die aan de Waalse socialisten een machtig wapen zouden geven, waartegen de katholieke Walen geen verweer zouden hebben. "Au dessus de l'attachement à la langue et au pays, nous plaçons l'attachement à la religion."

Op de tweede dinsdag van november zou het vernieuwde parlement bijeenkomen, zodat vanaf oktober de zenuwachtigheid groeide in politieke kringen. Met ingang van 19 oktober herschikte Jaspar zijn regering. Tschoffen kwam als derde christen-democraat in de ploeg als Minister van Koloniën. ${ }^{64} 0 \mathrm{~m}$ het bestaande evenwicht met de liberalen te bewaren werd er ook een liberale portefeuille gesplitst: de Oost-Vlaming Lippens behield de Spoorwegen, maar stond PTT af aan Forthomme van Verviers; er kwamen dus twee Walen bij in de regering. Tegelijk werd Albert Carnoy vervangen door de christen-democraat Jules Van Caenegem, die een meer uitgesproken flamingantisch profiel had.

Op 3 november 1929 vergaderde de Middenraad van het ACW om van zijn drie ministers uiteenzettingen te horen over de sociale wetgeving, de fiscale politiek en de aanpak van het talenvraagstuk. Minister Heyman gaf de verzekering dat de regering het initiatief zou nemen om dit laatste op te lossen. De vergadering drong aan op het onmiddellijk neerleggen van wetsontwerpen met het oog op een volledige oplossing binnen het komende parlementaire jaar, dus nog voor het eeuwfeest van het koninkrijk. (Die illusie leefde al vanaf de toespraak van Jaspar op 29 mei, ook in de Vlaamse Kamergroep.) De vergadering stelde een commissie

63. De Standaard wees met klem op de 300.000 Vlamingen in Wallonië, die veeleer bescherming nodig hadden dan de Franstaligen in Vlaanderen.

64. Tschoffen had in december 1922 ontslag genomen als volksvertegenwoordiger, omdat zijn Luikse achterban zijn verdediging van de vernederlandsing der Gentse universiteit niet nam. Hij was dan in 1924 tot senator gecoöpteerd. Hij zou in de kabinetsraad op 11 november 1929 tussenkomen: "Il faut avant tout fermer la plaie flamande." Maar hij legde op 27 december zijn portefeuille neer omdat de Luikse Banque Chaudoir, waarin hij lid was van de raad van bestuur, met faillissement bedreigd werd. M. Van Meerten, De jaren dertig op de beurs, in G. De ClercQ (ed.), Ter Beurze. Geschiedenis van de aandelenhandel in België, 1300-1990, Brugge, 1992, p. 259. Tschoffen zou opnieuw Minister van Koloniën worden van mei 1932 tot november 1934. Intussen werd de portefeuille beheerd door Jaspar, en daarna door de vroegere secretaris-generaal van het ministerie. 
aan om die verwezenlijking van het taalstatuut te bewaken. ${ }^{65}$ "De vergadering geeft opdracht aan de leden van de parlementsgroepen om te zorgen dat de wetsontwerpen betreffende de taalregeling spoedig worden besproken."

Op het perscommuniqué, waarin dat alles werd meegedeeld, reageerde het Vlaams-nationalistische dagblad De Scheldeop 6 november: "De eerste-minister zal zuurgekeken hebben toen hem dit kleine voorspel van wat hem in de Kamer te wachten staat, ter kennis werd gebracht." Inderdaad bleek het ACW het ernstig te menen. Op 5 november had Van Cauwelaert ook aan Jaspar geschreven dat hij niet zou aanvaarden dat de fiscale ontwerpen zouden worden goedgekeurd vóór de volledige afhandeling van de vernederlandsing van Gent. ${ }^{66}$

Bij de opening van de parlementaire zittijd waren verschillende partijcongressen voorzien. De Federatie van Katholieke Kringen congresseerde in Mons op 10 november. Dat was dus de conservatieve partijvleugel, de tegenhanger en in bepaalde opzichten tegenstander van het ACW, waarin de katholieke franskiljons traditioneel steun zochten. Maar ze werden daar nu zelfs niet aan het woord gelaten. Zes dagen tevoren publiceerde La Libre Belgique een Lettre de Catholiques gantois au Congrès catholique de Mons. Veertig edellieden en andere vooraanstaanden uit de Cercle Catholique van Gent, ondersteund door leden van de Société Générale des Etudiants catholiques, beklaagden zich in de uitvoerige brief dat hun geweigerd was om het woord te voeren op het congres. Daarom moeten we onze aanklacht over de nakende taalverdrukking en verscheuring van het vaderland kwijt via de pers, maar zelfs een Brussels blad met een priester aan het hoofd weigert die! (bedoeld wordt Le XXe Siècle van Wallez). ${ }^{67}$

Op het socialistisch partijcongres op 9 en 10 november werd alleen gehandeld over een taalregeling voor het onderwijs; bestuur, gerecht en leger werden terzijde gelaten. In het voorbereidend verslag van de Luikse volksvertegenwoordiger Léon Troclet, dat al was goedgekeurd door de Algemene Raad van de partij, werd gesteld dat de streektaal voertaal zou zijn in alle graden. Toch kwamen de Waalse voorstanders van tweetaligheid van Vlaanderen op dit congres aan het woord, in

65. De commissie vergaderde op 13, 19 en 26 november, blijkens de uitnodigingen die werden verstuurd aan veertien Vlamingen (Rubbens, Segers, Baers, Colens, Van Isacker, Van Hoeck, Logghe, Van Kerckhoven, Poullet, Marck, Broekx, Rutten, Debruyne en Vergels) en zeven Franstaligen (Behogne, Mathieu, Van Overbergh, Bodart, Legrand, Winandy en Pauwels).

66. AMVC, Dossier Frans Van Cauwelaert, C 1954/B.

67. Op het congres bleef oud-minister Renkin, die de toespraak over de taalkwestie had moeten houden, afwezig, volgens De Standaard (15 november) "omdat hem verbod was opgelegd de Gentse doodgravers af te keuren en ter verantwoording te roepen over hun werk van ontbinding zoals hij voornemens was geweest". De taalkwestie werd dus op het congres niet behandeld. Sinds 1927 ijverde Renkin voor het overnemen van de flamingantische eisen, als middel om de eenheid van de partij te versterken. 
een vinnig debat. Maar omdat het nu duidelijk was geworden dat dan ook tweetaligheid in Wallonië zou moeten toegestaan worden, werden hun amendementen verworpen. Het Compromis des Belges werd stilletjes losgelaten. Tegelijk werden toch de achterhoede-gevechten al ingezet: de universiteit van Gent mocht volledig vernederlandst worden, maar het akkoord hierop gold enkel als onderdeel van een gevraagde "algemene en volledige hervorming van het onderwijs in de zin van de culturele zelfstandigheid". ${ }^{68}$ Dus op Sint-Juttemis. Ofwel: mits Vlaamse tegenprestaties.

Het socialistisch congres besliste ook dat de partij in de oppositie zou blijven tot na nieuwe verkiezingen. Dat gaf aan de liberalen een absoluut vetorecht en daar maakten die onmiddellijk gebruik van. Ze weigerden de vernederlandsing van de Gentse universiteit ${ }^{69}$, die algemeen werd erkend als het eerste punt van de aangekondigde definitieve taalregeling. De regering dreigde te vallen.

Op 16 november schreef ACW-voorzitter Rubbens aan senator pater Rutten: "Volkomen t'akkoord met uw nota [...] Wij mogen niet transigeren, in het belang van België zelf. Een "parlementaire" oplossing dient tot niets als de gemoederen niet bevredigd worden. Het is nu de laatste kans die België heeft om te bewijzen dat het de Vlaamse kwestie kan oplossen. De meeste Vlaamse intellectuelen geloven dat niet meer. Zij achten de tegenstelling Vlaanderen-België onoverbrugbaar!"

Op 19 november vergaderden de katholieke Kamer- en Senaatsfracties gezamenlijk en schaarden zich unaniem - Walen en Vlamingen - achter de volledige vernederlandsing van de Gentse universiteit. ${ }^{70}$ Net zomin als op de vergadering van de Vlaamse Kamergroep op 13 november ${ }^{71}$ was er sprake geweest van toegevingen aan de liberalen.

Op 20 november verklaarden de liberale parlementsgroepen hun verzet tegen de vernederlandsing van de universiteit op te willen geven, maar alleen in ruil voor waarborgen voor Franstalig lager en middelbaar onderwijs in Vlaanderen. Op 25 november viel de regering. Op 1 december besliste de Landsraad van de liberale partij dat haar ministers het wetsontwerp ter vernederlandsing van de universiteit

68. L. WiLs, Bormsverkiezing [...], pp. 378-379.

69. Het enige wat de liberale ministers wilden toestaan in de kabinetsraad van 11 november, was een toevoeging van de ontbrekende Nederlandstalige colleges, maar geen schrapping van Franstalige. Wanneer minister de Broqueville opperde om aan de universiteit van Luik enkele Nederlandstalige keuzevakken in te voeren voor de Limburgse studenten, om zo Franstalige colleges in Gent meer aanvaardbaar te maken, viel Tschoffen in dat dit "serait complètement irréalisable et repoussé énergiquement par toute la Wallonie. ”Ook op 14, 21 en 25 november geraakte de kabinetsraad er niet uit, blijkens de notulen.

70. Bron: De Standaard. Van de unanieme beslissing van de rechterzijde wordt geen melding gemaakt door C.H. HöJER, Le régime parlementaire belge [...], noch door H.J. ELIAS, Vijfentwintig jaar Vlaamse Beweging 1914-1939, deel 3, Antwerpen, 1969.

71. Notulen in KADOC, Papieren Van Isacker. 
mochten ondertekenen, maar dat ze bij de uitwerking van het taalstatuut aan de tweetaligheid van Vlaanderen moesten vasthouden. ${ }^{72}$

Tegelijkertijd, op 30 november en 1 december 1929, congresseerde het ACW. Het keurde het verslag goed dat door de taalcommissie van de beweging was opgesteld om het "taalstatuut" dat door de Middenraad in maart was gelanceerd, breedvoeriger uit te werken. Voor het lager en middelbaar onderwijs werd daarbij gestipuleerd dat "zowel het vrije als het officiële" onderwijs volgens het beginsel van de eentaligheid der streken moest worden ingericht. De reeks wetten waarin het taalstatuut zou worden gegoten, ook die inzake gerecht, administraties en leger, "moet afgewerkt zijn vooraleer het parlement uiteen gaat, vóór de feesten van 1930." "73 Dat werd allemaal geëist onder sterke druk van de basis. ${ }^{74}$

De regering kwam op 4 december weer op de been doordat de koning haar ontslag weigerde, maar ze bleef in volle dubbelzinnigheid steken zoals bleek bij haar programmaverklaring voor de Kamer op 10 december. Jaspar beloofde de oplossing van het talenvraagstuk in de lopende zittijd, met vernederlandsing van de Gentse universiteit waarvoor hij onmiddellijk het wetsontwerp neerlegde, met doorvoering van het hangende flamingantische wetsvoorstel op het gerecht, en aanpassingsmaatregelen bij de administratieve taalwet. Voor het leger zou worden gewacht tot de volledige toepassing van de wet van 1928, om zo nodig verbeteringen aan te brengen. Dat was allemaal ongeveer conform de eisen van het ACWcongres. Maar tegemoetkomend aan de liberale stellingname was een regeling toegevoegd voor het lager en middelbaar onderwijs volgens het beginsel: moedertaal is onderwijstaal, met erkenning van de vrijheid van het gezinshoofd. Welnu, de regering kreeg het vertrouwen van katholieken en liberalen, maar de tweetaligheid van het onderwijs in Vlaanderen werd uitdrukkelijk afgewezen door Van Cauwelaert, de voorzitter van de Vlaamse Kamergroep, en door Hendrik Marck, een vooraanstaand lid van de Democratische Kamergroep waarvan hij in 1931 voorzitter zou worden. ${ }^{75}$ Tijdens de volgende maanden probeerden de socialisten

72. C.H. HÖJER, Le régime parlementaire belge [...], p. 188; H.J. ELIAS, Vijfentwintigjaar [...], deel 3, pp. 31-32.

73. VIIle Congres van het Algemeen Christen Werkersverbond van België - 30 November - 1 December 1929. Verslag voorgedragen door de Taalcommissie van het A.C.W., Antwerpen, s.d., p. 3. 74. KADOC, Archief ACW, LXXV, 281/2; de hevige, op grote schaal verspreide eisen van het arrondissementeel Werkersverbond Antwerpen op 13 oktober, en van het Werkersverbond WestVlaanderen op 18 november 1929.

75. C.H. HöJER, Le régime parlementaire belge [...], p. 188; A.W. WILLEMSEN, Het Vlaamsnationalisme. De geschiedenis van de jaren 1914-1940, Utrecht, 1969, p. 257. Het ACW ging niet in op de vraag van zijn Werkersverbond van het arrondissement Antwerpen (voorzitter H. Marck) op 17 december 1929 om de Middenraad samen te roepen over "wat er ontbreekt in het taalprogramma der regering volgens de taalcommissie van het $A C W$ ”; KADOC, Papieren Segers, nr. 5.1.4. 
in Kamer en Senaat, met inbegrip van senator August Vermeylen, de behandeling van het regeringsontwerp op de vernederlandsing van de universiteit te beletten. Pas toen op 6 februari 1930 de bespreking begon in de Kamer, beslisten hun volksvertegenwoordigers dat de stemming hierover vrij zou zijn, en weldra kondigde hun leider Vandervelde aan dat hij vóór zou stemmen. ${ }^{76}$ Tevoren hadden zij gehoopt dat ze de regering zouden doen vallen over de zaak, en de bestaande taaltoestanden bewaren. Inderdaad had de regering bij koninklijk besluit een commissie opgericht die een compromis over het lager en het middelbaar onderwijs moest zoeken, nog vóór de goedkeuring van het wetsontwerp over de universiteit. ${ }^{77}$ De socialisten hadden geweigerd er deel van uit te maken, en mochten erop rekenen dat de katholiek-liberale tegenstelling wel onoverbrugbaar zou blijken. Maar bij gebrek aan alternatief bleef de coalitie overeind.

Bij de bespreking in de Kamer steunde C. Huysmans met succes de socialistische wallingantische eisen dat Jaspar moest beloven dat in de komende globale taalregeling slechts een beperkt aantal hogere ambtenaren de tweede taal zou moeten kennen (wat het ACW ook aanvaard had), en dat de huisvaders vrije taalkeuze zouden bekomen inzake onderwijs (in Vlaanderen). Het regeringsontwerp werd dan ongewijzigd aangenomen, met een grote meerderheid. De wet van 5 april 1930 vernederlandste dus de rijksuniversiteit Gent, met ingang van oktober $1930 .^{78}$

Vóór het eeuwfeest kwam er geen andere taalwet meer door. Omwille van Jaspars belofte aan de liberalen, moest de wet op het lager en middelbaar onderwijs voorrang krijgen. Omdat het ACW zoals de hele katholieke flamingantische opinie op zijn standpunt bleef en de wallingantische vrees voor tweetaligheid in Wallonië wist aan te wakkeren, zou er daarover toch een bevredigende wet komen, samen met een andere op de overheidsadministraties, maar pas in de lente van 1932. In de katholiek-liberale commissie die een onderwijscompromis moest ontwerpen had Van Cauwelaert niet willen zetelen, zodat hij zijn onafhankelijkheid als voorzitter van de Vlaamse Kamergroep behield. ${ }^{79}$ Het ACW was wel sterk in de

76. K. De ClercK, Kroniek van de strijd [...], 18 december 1929, 30 januari, 6 en 19 februari 1930.

77. Notulen kabinetsraad 9 en 23 december 1929 en 8 januari 1930.

78. H.J. Elias, Vijfentwintig jaar [...], deel 3, pp. 32-33.

79. Brief van Frans Van Cauwelaert aan Jan Boon, de hoofdredacteur van De Standaard, 11 februari 1930: "Wat de commissie zelf betreft, hebt gij volkomen gelijk te doen uitschijnen dat deze commissie over geen enkel gezag beschikt dat de partijen voor het parlement zou binden. Het is enkel een consultatieve groep door de Regering verkozen. Wij behouden onze volle vrijheid om achteraf de voorstellen af of goed te keuren welke uit haar werk zullen voortvloeien. Om deze vrijheid niet te laten beperken, heb ik geweigerd deel uit te maken van de commissie, en ik behoef $U$ niet te herhalen dat ik 
commissie vertegenwoordigd, met zijn voorzitter Rubbens, met Poullet die voorzitter van de commissie werd, Van Isacker, en pater Rutten die de belangrijkste onderhandelaar met de liberalen zou worden. Om de regering te redden en de belofte van Jaspar uit te voeren, en omdat aartsbisschop Van Roey erop aandrong, stelde Rutten teksten voor die wel een verbetering inhielden van de bestaande toestand - inzake het lager onderwijs in Brussel, en inzake het middelbaar onderwijs - maar geen eentaligheid van de landstreken. Zijn teksten ${ }^{80}$ werden steeds weer aangepast onder de hevige kritiek van de flamingantische opinie, en de toenemende kritiek van wallingantische kant, nu het duidelijk werd dat ze ook op Wallonië zouden van toepassing zijn. Zodat er een tegenstelling groeide tussen de Waalse liberalen en hun Brusselse en meeste Vlaamse partijgenoten. ${ }^{81}$ In de geschiedschrijving werd wel gewezen op de flamingantische agitatie, bijzonder op die van De Standaard die was geradicaliseerd sinds 1 september 1929, toen GustaafSap de politieke leiding ervan had overgenomen van Van Cauwelaert. ${ }^{82}$ Maar wat niet werd opgemerkt was dat het ACW weigerde het regeringsakkoord met de liberalen te erkennen. Het verwierp de voorstellen der commissie en later

geen de minste tol wil betalen tegenover de liberale partij om hare instemming met de vervlaamsing der Gentse Hogeschool te verkrijgen." KADOC, Papieren Boon, nr. 4.2.1. Daags tevoren had Van Cauwelaert aan Poullet geschreven, met kopie aan Van de Vyvere, Blavier, Rubbens en Van Isacker: ontbind die commissie of schort ze op, want ze wekt veel wantrouwen bij de Vlaamse opinie; AMVC, Dossier Frans Van Cauwelaert, C 1954/B.

80. Van Cauwelaert daarover aan Jan Boon, 11 februari 1930: "Het is één van die vele principiële verklaringen welke men gelijk een wassen neus bij de praktische toepassing kan draaien zoals men wil ... Blijkbaar met opzet is de steller van het amendement in het onbepaalde gebleven", zodat zijn Franstalige klassen konden herleid worden tot transmutatieklassen. Hij had er bovendien een bijzondere subsidiëring door het Rijk, voor personeel en uitrusting, aan gekoppeld, wat een breekijzer kon betekenen voor het vrij onderwijs; KADOC, Papieren Boon, nr. 4.2.1. Juist dat laatste maakte de zaak nog minder aanvaardbaar voor de linkse wallinganten.

81. Al op 12 mei 1930 stelde Jaspar vast in de kabinetsraad, over de ontwerpen die waren opgesteld op verzoek van Devèze en zijn liberale vrienden, tegen de wens van de Vlaamse rechterzijde: "Or, on constate dans la presse une opposition violente de certains libéraux wallons qui accusent le Gouvernement de flamingantisme, précisément à cause des projets. M. le Premier Ministre fait ressortir que cette situation est intolérable et qu'il importe que les libéraux vident leurs querelles entre eux"; Notulen. In de bestuursvergadering van de anti- flamingantische Association libérale van Antwerpen op 26 september 1930, stelde volksvertegenwoordiger Paul Baelde vast dat de motie die in december 1929 was goedgekeurd door de nationale Federatie van de partij, achteraf door de Waalse liberale volksvertegenwoordigers werd verworpen, toen ze merkten dat de wet ook bij hen van toepassing zou zijn; Verslagboek.

82. Op 29 januari 1930 klaagde Van Cauwelaert bij hoofdredacteur Boon dat die bezig was "nodeloos wantrouwen tegen onze eigen vrienden op te wekken" door "de volstrekte afwezigheid van ieder woord omtrent de pogingen welke van katholieke Vlaamse zijde volhardend worden gedaan om Kamer en Regering in de goede richting te houden"; KADOC, Papieren Boon, nr. 4.2.1. 
het regeringsontwerp, al was dat door alle ministers ondertekend. Zo deed het Hoofdbestuur op 25 februari 1930, de ACW-taalcommissie op 27 mei, de Middenraad op 29 juni en op 31 juli, nadat het Westvlaamse weekblad De Volksmacht er campagne tegen gevoerd had. ${ }^{83}$

Op diezelfde 31 juli 1930 had Jaspar een wanhopige protestbrief van zeven bladzijden geschreven aan minister Heyman, dreigend met ontslag indien de Vlaamse katholieke ministers en vooraanstaanden de regering en het land niet verdedigden tegen de aanvallen van hun pers. Hij somde alle zaken op die zijn regering sinds december verwezenlijkt had om de taalkwestie te regelen. Maar sinds het neerleggen van het wetsontwerp op het onderwijs zag hij "un déchaînement de passions". In de voorbije weken waren er De Standaard, het DavidsfondsAntwerpen, de Vlaamse Toeristenbond (VTB), en volksvertegenwoordiger Bodart die in een interview - dat uiteraard de ronde deed van de flamingantische pers - zegde dat de christelijke arbeidersbeweging de belofte van Jaspar aan de Brusselse liberalen niet moest inlossen. ${ }^{84}$

Daarna kon Jaspar in de kranten de motie lezen van de Middenraad van het ACWLNTC, waarin de wetsontwerpen werden afgewezen omdat ze het beginsel 'streektaal is voertaal' ontzenuwden door hun uitzonderingen en omdat ze inbreuk maakten op de gemeentelijke zelfstandigheid. Na die motie maakten de ontwerpen gewoon geen kans meer. La Libre Belgique van 2 augustus concludeerde terecht dat dit het ontslag of de val van Jaspar betekende.

Jaspar diende de regeringsontwerpen nog in bij de Senaat, waarin de flaminganten en christen-democraten traditioneel zwakker stonden dan in de Kamer. Maar hoewel in september-oktober de Franstalige liberalen en socialisten meer water bij hun wijn deden, kregen ze van flamingantische kant geen tegemoetkoming. In de kabinetsraad van 7 november verklaarde Jaspar, blijkens de notulen, "niet te kunnen aanvaarden dat men aan de Vlaamse bourgeoisie een uitsluitend vlaamstalig middelbaar onderwijs oplegt". In mei 1931 nam hij ontslag toen de ontwerpen van taalwet in het parlement moesten besproken worden en de tegenstelling tussen het $\mathrm{ACW}$ en de liberale regeringspartner ook inzake defensie onoverbrugbaar bleek. Jules Renkin die een nieuwe katholiek-liberale regering vormde, was bereid het Vlaamsgezinde standpunt te aanvaarden. Hij onderhandelde over het programma met Van Cauwelaert en zijn Vlaamse Kamergroep, en nam in zijn ploeg vier flaminganten op onder wie de christen-democraten Hendrik Heyman, Jules Van Caenegem en Philip Van Isacker. Een jaar later lokten de liberalen nog een regeringscrisis uit, omdat hun eis van Franstalig onderwijs in Vlaanderen geweigerd werd door de Kamer. Bij de vorming van zijn nieuwe regering onderhandelde

83. KADOC, Archief ACW, 66.1 en LXXV, 281/2.

84. KADOC, Papieren Heyman, nr. 8.1.2. 
Renkin toen opnieuw met de Vlaamse Kamergroep en ook met het ACW. Het is van belang hierbij stil te staan.

"De Democratische Groepen (van Kamer en Senaat) en de ACW-bestuursorganen coördineerden toen hun actie [...] en stelden drie voorwaarden voor regeringsdeelname, wat zij tevoren nooit zo uitdrukkelijk hadden gedaan: drie ministerportefeuilles ... behoud van de sociale wetgeving, oplossing van de Vlaamse kwestie volgens de wens van de parlementaire meerderheid. Met die laatste eis stelde het unitaire ACW zich eens te meer achter Van Cauwelaert", namelijk dat de regering de vertrouwenskwestie niet zou stellen, zodat de liberalen geen vetorecht hadden en er een oplossing kon doorgedrukt worden met medewerking van socialisten. ${ }^{85}$ In de steeds verergerende economische crisis "moest het $A C W$ stilaan terrein prijggeven". Het kreeg slechts twee portefeuilles en een gedeeltelijke "sociale afbraak" kon het niet beletten. ${ }^{86}$ Maar de taalwetten op het onderwijs en op de overheidsadministraties werden in juni-juli 1932 doorgedrukt volgens zijn flamingantisch standpunt, mede dank zij socialistische medewerking.

\section{Epiloog}

Het duurde tot 1935 eer de taalwet op het gerecht werd uitgevaardigd en tot 1938 voor die op het leger. Waarom moest dat zolang duren? Er was de economische crisis die gedurende enkele jaren de aandacht opeiste, plus het taaie verzet van de liberale partij, en de terugkeer van de socialisten naar een anti-Vlaamsgezinde opstelling bij de behandeling van de wetten op het gerecht en het leger.

Er was ook de tussenkomst van Albert I, die heel sterk de liberale partij en de liberale opvattingen was toegedaan, onder meer op taalgebied. Hij had in 19181923 , ten tijde van de grondwetsherziening en onmiddellijk daarna, de verwezenlijking van het Vlaamse minimumprogramma kunnen beletten. Voor hem moest de Belgische eenheid steunen op de tweetaligheid van Vlaanderen en de wettelijke onderschikking van het Nederlands aan het Frans. ${ }^{87}$

Op 5 november 1931 wenste Albert Eerste minister Renkin geluk met de goedkeuring door de Senaat van het wetsontwerp op het middelbaar onderwijs, dat nog door Jaspar was ingediend en waarin enigszins was tegemoetgekomen aan de verzuchting voor tweetaligheid in Vlaanderen. ${ }^{88}$ Maar op 24 januari 1932

85. E. Gerard, De Katholieke Partij [...], p. 303.

86. E. Gerard, De Katholieke Partij [...], p. 304.

87. L. WiLs, Honderd Jaar [...], Deel 2 [...], pp. 69 tot 169; L. WILS, Koning Albert I en het minimumprogramma, in: Wetenschappelijke Tijdingen, jg. 54, 1995, nr. 3, pp. 167-171; L. WILS, De taalpolitiek [...].

88. J. Stengers, De Koningen der Belgen. Macht en Invloed, Leuven, 1992, p. 24. 
dreigde hij hem, zijn handtekening te zullen weigeren onder de taalwet op de besturen, die in behandeling was bij de Kamer: iets wat voorbereidde op "une séparation administrative plus ou moins larvée du pays" zou immers een politieke scheiding aankondigen, met de ineenstorting van het land als uiteindelijk gevolg. ${ }^{89}$ De Kamercommissie had namelijk de tweetaligheid bij de hogere centrale ambtenaren geschrapt, en de bepaling toegevoegd dat de centrale administraties zoveel mogelijk moesten worden gesplitst in eentalige diensten. Op 27 januari deed Renkin in de Kamer een alternatief voorstel: de splitsing van diensten moest aan de regering worden overgelaten, en wanneer een eentalig (Waals) ambtenaar een centraal ambt bekleeddde, zou hij bij de behandeling van de anderstalige dossiers door een tweetalig adjunct worden bijgestaan. Van Cauwelaert zegde onmiddellijk zijn steun toe aan deze alternatieve formule om aan het Waalse veto tegen verplichte tweetaligheid van de hogere ambtenaren tegemoet te komen, en de Kamer nam de regeringsamendementen aan. De formule die in de wet kwam, en er staat tot nu, was dus de "stupidité" die Poullet herhaaldelijk verklaard had te willen begaan, om uit het slop te geraken.

Renkin liet de taaltoestanden in de administratie verder regelen in de zin van gelijkheid tussen de twee landstreken, en ook die in het middelbaar onderwijs, alles tegen de zin van de liberalen. Nadat de liberalen winst hadden geboekt in de gemeenteraadsverkiezingen van oktober van dat jaar, ontsloeg de koning Renkin met het verwijt dat hij in de aanslepende economische crisis de financiën niet in de hand hield. De nieuwe parlementsverkiezingen brachten de liberalen niet de verhoopte winst, maar tijdens de volgende jaren wisten ambtenaren en burgemeesters terdege dat ze geen koninklijke sanctie moesten vrezen wanneer ze weigerden de taalwet op de besturen na te leven, op dezelfde manier in Vlaanderen als in Wallonië.

Koning Albert zal zichzelf ervan overtuigd hebben dat hij in taalaangelegenheden geen liberale of wallingantische, maar een nationale politiek voerde. Had die immers ook niet de sympathie van een groot deel van de katholieke Franstalige pers? Bij de genoemde gemeenteraads- en parlementsverkiezingen van 1932 kwam in Gent tegen de katholieke partij een Union Catholique op, met de steun van het plaatselijk dagblad Le Bien Public en van La Libre Belgique. Het was dezelfde groep uit de Cercle Catholique die in 1929 tevergeefs had willen protesteren op het congres van de Federatie van Katholieke Kringen, tegen het taalprogramma dat de Katholieke Unie had aangenomen. Voor de gemeenteraad kwam de groep op samen met een Corporatief Verbond, en haalde een verkozene. Voor de Kamer haalde ze 4.664 stemmen, 3,20\% van de stemmen in het

89. J. Stengers, Evolution historique de la royauté en Belgique, in: Res Publica, 1991, p. 101. Vgl. M.R. Desmed-Thielemans, Albert I, in: België en zijn Koningen, Brussel, 1990, p. 93. 
arrondissement, maar lang niet voldoende voor een zetel. ${ }^{90}$ Voor de provincieraad trok ze zich daarna terug, op vraag van de bisschop. ${ }^{11}$

In die parlementsverkiezingen kwam niet alleen het $\mathrm{ACW}$ op met een sterke beklemtoning van zijn flamingantisch karakter en programma. ${ }^{92}$ Het twaalfpunten-programma van de Katholieke Unie luidde onder nummer vier: "Eerlijke toepassing der taalwetten op alle gebied. Voltooiing van de definitieve, vlugge en nationale oplossing van het talenvraagstuk door het stemmen van een wet in burgeren handelsrechtelijke zaken en door het herzien van de wet op het gebruik der talen in het leger. In de Brusselse agglommeratie eerbied voor de wettelijke gelijkheid op taalgebied en erkenning der wederkerige rechten van Vlaams- en Franssprekende inwoners. "Dat werd ook opgenomen in de verkiezingspropaganda van de Federatie van Katholieke Kringen. ${ }^{93}$

\section{Besluit}

De taalwetgeving van 1929 en de volgende jaren erkende de eentaligheid van Vlaanderen, m.a.w. erkende het recht van een Vlaams volk op culturele integriteit. Omwille van het grote belang daarvan, is er sindsdien veel inkt gevloeid over de verklaring van die wending. De simplistische uitleg dat de Bormsverkiezing het wonder had teweeggebracht, werd verlaten voor een meer genuanceerde voorstelling. Daarin werd benadrukt dat de kentering al tevoren aan de gang was, onder de druk van het katholieke flamingantisme, druk die in 1928 sterk was opgevoerd en al had geleid tot een splitsing van legerafdelingen volgens de taal. Dat behalve de Bormsverkiezing en de nationalistische overwinning in de algemene parlementsverkiezingen van mei 1929, ook heel de nationalistische en Groot-Nederlandse drukking van de eerste helft van 1929 moet worden in rekening gebracht. En dat de nederlaag van het wallingantisch Compromis des Belges ook een essentiële factor uitmaakte. Dat alles samen bracht de regering Jaspar-Hymans tot haar beslissing in juni 1929. "De kogel was door de kerk", schreef Lode Wils nog in $1994 .{ }^{94}$

90. De katholieke partij haalde 59.557 stemmen, of 40,81\%; E. De SMEt, R. Evalenko en W. Fraeys, Atlas [...], p. 126.

91. KADOC, Papieren August De Schryver, nrs. 8.1.4.1 en 8.2.3. Als voorzitter van de katholieke partij in Gent had De Schryver haar flamingantisch karakter benadrukt en de scheuring op de koop toe genomen.

92. Zie de brochure van 55 bladzijden Algemeen Christelijk Werkersverbond van België. Wetgevende Verkiezingen 1932, s.l., s.d.

93. Nr. 56 van haar mededelingenblad Nota's en Bescheiden, 10 november 1932.

94. L. WiLs, Bormsverkiezing [...], het citaat p. 360. 
Het is nu wel duidelijk dat de kogel in juni 1929 helemaal niet door de kerk was. Er was nog negen jaar strijd nodig. Die werd gevoerd "tussen de Vlaamse Rechterzijde en de liberalen. De Katholieke Vlaamse parlementsgroepen werden gesteund door het $A C W$ en de Boerenbond en in de rug geduwd door de K.V. Landsbond, het Davidsfonds en de Standaard", aldus Emmanuel Gerard in 1985.95 Ook die voorstelling moet nu genuanceerd worden. Het ACW heeft niet alleen gesteund, het heeft ook - en sterk - geduwd. De belangrijkste verandering van 1929 is dat het nationale, unitaire ACW-LNTC de taalkwestie tot één van zijn belangrijkste programmapunten heeft genomen, in plaats van het over te laten aan zijn Vlaamse Werkersbonden en verkozenen. Juist tijdens deze en de volgende jaren ging het krachtig als een zelfstandige partij optreden, met de flamingant Hendrik Marck als voorzitter van de Democratische Kamergroep sinds juni $1931 .{ }^{96}$ Onjuist blijkt ook de voorstelling dat de Katholieke Vlaamse Kamergroep "meer fractiedwang kon uitoefenen dan wie ook, buiten de regering zelf ". ${ }^{97}$ Ze kon en deed dat méér dan de regering, maar de Democratische Kamergroep misschien nog meer, tenminste in de jaren dertig.

Het ACW heeft zijn flamingantisch programma kunnen doen overnemen door de Katholieke Unie en door de katholieke parlementsfracties, alweer Walen en Vlamingen samen. Dat was mogelijk omdat al sinds een eeuw de clericale opinie, ook de Franstalige, veel meer dan de anticlericale opinie open stond voor de Vlaamse beweging. Het was ook mogelijk omdat de flaminganten zich hebben neergelegd bij de Waalse eis - inderdaad niet alleen een wallingantische, maar op een aantal katholieken na een algemene Waalse eis - van de eentaligheid van de ambtenaren. In feite was dat natuurlijk een onmogelijkheid, wat Poullet tweemaal een "stupidité" noemde die hij terwille van de bevrediging zou willen goedkeuren. Op dat punt was de administratieve taalwet van 1932 voor de Vlaamsgezinden een achteruitgang vergeleken bij die van 1921, welke onuitvoerbaar bleek tengevolge van de Waalse weigering: zelfs La Terre Wallonne noemde deze la loi von Bissing. De quadratuur van de cirkel die moest worden opgelost, was immers de volgende. De flaminganten vroegen gelijkheid. De meeste Walen vroegen absolute eentaligheid van Wallonië plus onbeperkte carrièremogelijkheden zonder tweetaligheid. De koning, de liberalen, de wallinganten en de franskiljons voerden terecht aan dat een combinatie van beide eisenpaketten ondoenlijk was en het land zou doen uiteenvallen. Ze hielden daarom vast aan de tweetaligheid van Vlaanderen en bestempelden de flamingantische gelijkheidseis als onvaderlands. De flaminganten hebben, het ACW als eerste, de Waalse eis ingewilligd om tenminste de gelijkheid in rechte te bekomen.

95. E. Gerard, De Katholieke Partij [...], p. 296.

96. E. Gerard, De Katholieke Partij [...], pp. 301-303.

97. L. WILs, Bormsverkiezing [...], p. 363. 
Het doel van het ACW in 1929 was een nationale bevrediging te bereiken, Vlaanderen met België te verzoenen. Dat is slechts gedeeltelijk gebeurd, omdat de tegenstanders de verwezenlijking van de "gelijkheid in rechte" hebben weten uit te stellen tot 1932, tot 1935 voor het gerecht en 1938 voor het leger, om van de "gelijkheid in feite" te zwijgen. Mede tengevolge daarvan heeft de collaboratie in de Tweede Wereldoorlog een abnormale omvang gekregen, iets waarvan de gevolgen doorwerken tot nu. Ze dragen bij tot het uiteenvallen van het land, zowel als de Waalse afwijzing van tweetaligheid.

Em. Prof. DR. Lode WiLS Graaf de Grunnelaan 14, B-3001 Heverlee

Prof. DR. EMMANUel Gerard Kortrijksestraat 351, B-3010 Kessel-Lo 